\title{
Primary Cutaneous Diffuse Large B-Cell Lymphoma - a Case Report
}

\author{
Milena MILOVANOVIĆ ${ }^{1, *}$, Željko MIJUŠKOVIĆ ${ }^{1}$, Lidija KANDOLF SEKULOVIĆ1, \\ Olga RADIĆ-TASIĆ ${ }^{2}$, Olivera TARABAR ${ }^{3}$, Danijela MIJUŠKOVIĆ-JANKOVIĆ ${ }^{4}$ and Milica RAJOVIĆ5 \\ ${ }^{1}$ Department of Dermatology and Venereology, Faculty of Medicine, Military Medical Academy, Belgrade, Serbia \\ ${ }^{2}$ Institute of Pathology and Forensic Medicine, Military Medical Academy, Belgrade, Serbia \\ ${ }^{3}$ Department of Hematology, Faculty of Medicine, Military Medical Academy, Belgrade, Serbia \\ ${ }^{4}$ Institute of Radiology, Military Medical Academy, Belgrade, Serbia \\ ${ }^{5}$ Department of Plastic Surgery and Burns, Military Medical Academy, Belgrade, Serbia \\ *Correspondence: Milena Micković, E-mail: milenamickovic1987@gmail.com \\ UDC 616.5-006.44:615.849
}

\begin{abstract}
In 2005, the World Health Organization - European Organization for Research and Treatment of Cancer (WHOEORTC) classified cutaneous B-cell lymphomas into 4 categories: primary cutaneous marginal zone B-cell lymphoma (PCMZL), primary cutaneous follicle center lymphoma (PCFCL), primary cutaneous diffuse large $B$-cell lymphoma, leg type (PCDLBCL-LT), and primary cutaneous diffuse large B-cell lymphoma, other (PCDLBCL-O). The absence of evident extra-cutaneous disease is a necessary condition for the diagnosis of primary cutaneous B-cell lymphomas, because they have a completely different clinical behavior and prognosis from their nodal counterparts. PCDLBCL-O basically represents a morphological variation, lacking the typical features of PCDLBCL$L T$, neither confirming the definition of PCFCCL, but on the clinical ground, its behavior seems at least to partially overlap the indolent course of PCFCCL. In fact, the present WHO lymphoma classification from 2008 overcame the previous WHO-EORTC classification, including at least a part of PCDLBCL-O within the spectrum of PCFCCL. However, owing to the rarity and heterogeneity of the PCDLBCL-O, the precise clinicopathological characteristics have not been well characterized and the optimal treatment for this group of lymphomas is yet to be defined. Nevertheless, dermatologists and pathologists should be aware of this entity in order to avoid unnecessary aggressive treatment. We present a case of a 46-year-old Caucasian male with one large round-shaped tumor and a few scattered nodules localized on the back. The histopathological features of the lesion corresponded to PCDLBCL-O. The patient follow-up showed that he was disease-free three months after surgical excision of the lesions and adjuvant local radiotherapy. No additional therapy was introduced, including chemotherapy with rituximab, cyclophosphamide, doxorubicin hydrochloride, oncovin, prednisolone (R-CHOP).

Key words: Lymphoma, Large B-Cell, Diffuse; Skin Neoplasms; Diagnosis; Radiotherapy; Treatment Outcome;
\end{abstract} Case Reports

\section{Introduction}

The issue of primary cutaneous B-cell lymphomas (PCBCLs) other than marginal zone lymphoma (MZL) classification has been a matter of debate. In the previous World Health Organization - European Organization for Research and Treatment of Cancer (WHOEORTC) classification $(2005)(2,3)$ cutaneous diffuse large $\mathrm{B}$-cell lymphomas had several variants, including PCDLBCL-LT, cases with peculiar morphology (T-cell/histiocyte rich, plasmablastic) as well as diffuse lymphomas of centroblastic-like cells, intermingled with a mixed inflammatory infiltrate and with variable expression of BCL2, which are named primary cutaneous diffuse large B-cell lymphoma, other (PCDLBCL-O). PCDLBCL-O basically represents a morphological variant lacking the typical features of PCDLBCL-LT, neither confirming the definition of PCFCCL, whereas on the clinical ground, its behavior seems at least to partially overlap the indolent course of PCFCCL. In fact, the present 2008 WHO lymphoma classification overcame the previous WHO-EORTC and included at least a part of PCDLBCL-O within the spectrum of 


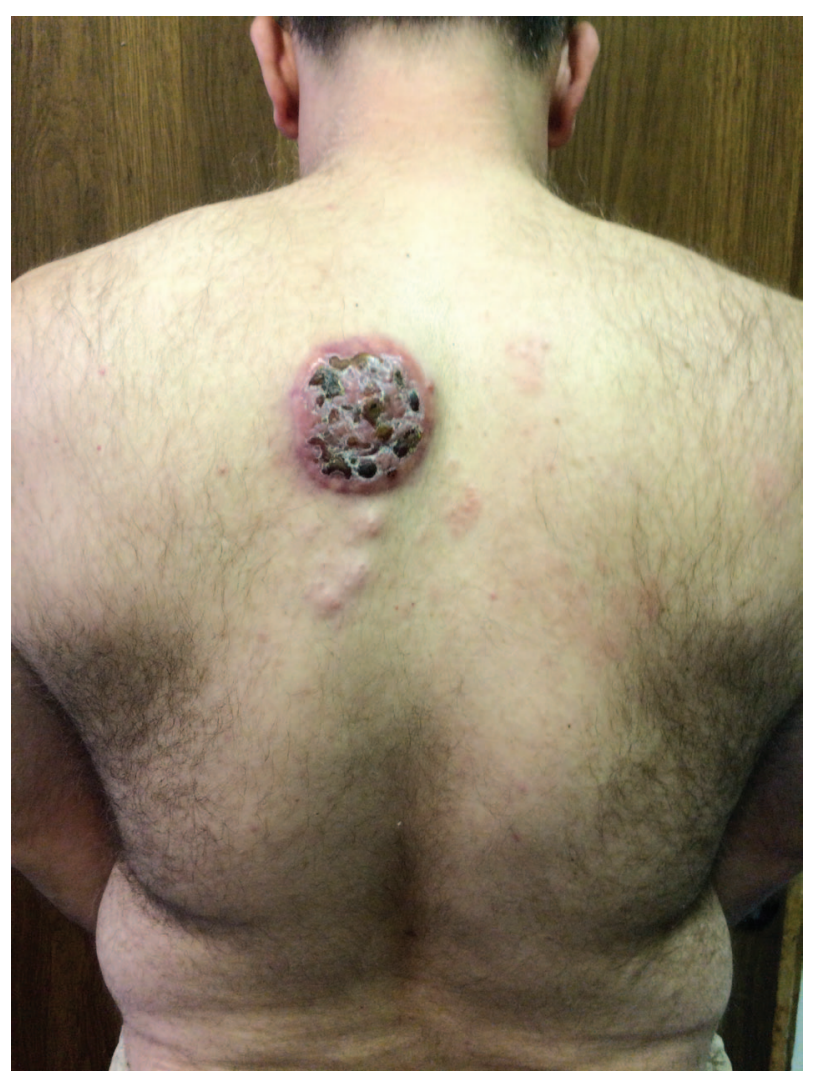

Figure 1. Clinical presentation of tumors and nodules in the left paravertebral region

PCFCCL (4). The absence of evident extracutaneous disease is a necessary condition for the diagnosis of PCBCLs because they have a completely different clinical behavior and prognosis from nodal counterpart (5).

\section{Case Report}

A 46-year-old Caucasian male was admitted to our department with an asymptomatic tumor on his back, in the left paravertebral region, that appeared two months earlier. It began growing rapidly, changing color to red and livid with formation of vesicles on the tumor surface, with hemorrhagic crusts upon drying. Also, smaller, new nodules appeared below the lower borderline of the tumor during the following month. Neither systemic symptoms, nor palpable lymphadenopathy were observed. The patient was otherwise healthy. There was no family history of malignancy.

Clinical examination of the patient's back revealed a large, asymptomatic, round shaped and well-demarcated tumor with elevated ery- thematous border located in the left paravertebral region. It was approximately $6 \mathrm{~cm}$ in diameter, and covered with multiple yellowish and black hemorrhagic crusts. In addition, close to the lower border of this tumor, three separate, well-demarcated, skin-colored nodules were noticed (Figure 1 and Figure 2).

Upon admission, tumor biopsy was performed from 2 separate sites. The histopathologic analysis of these two samples showed a diffuse infiltration of large centroblasts with a typical morphology - large nucleus, small basophilic cytoplasm and multiple scattered nucleoli (Figure 3).

On immunohistochemical (IHC) analysis, the infiltrated cells were positively stained with CD20 and Bcl6. There was no evident expression of CD3, CD5, CD10, CD23, MUM1 and $\mathrm{Bcl} 2$. (Figure 4). Fluorescence in situ hybridization (FISH) on skin samples for MYC oncogene was negative, which excluded the possibility of a double-hit lymphoma.

Complete and differential blood cell count, ESR, glucose, urea, serum creatinine, total proteins, albumins, uric acid, total bilirubin, electrolytes, iron, liver enzymes and C-reactive protein were within physiological

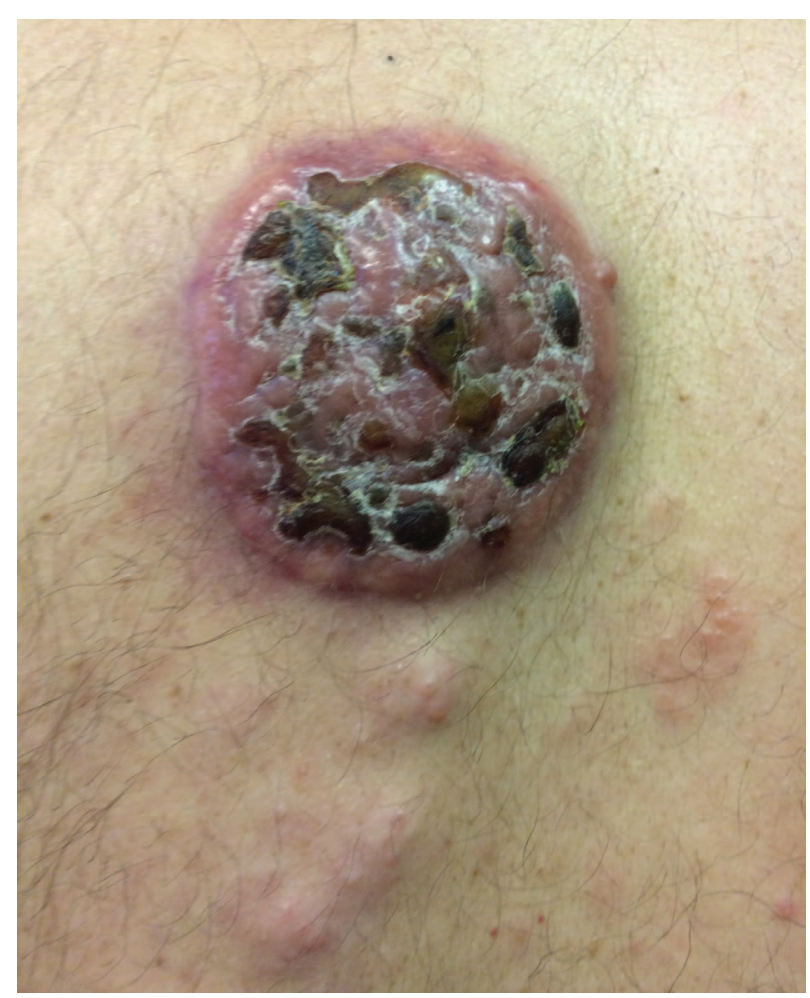

Figure 2. Close-up of tumors and nodules 


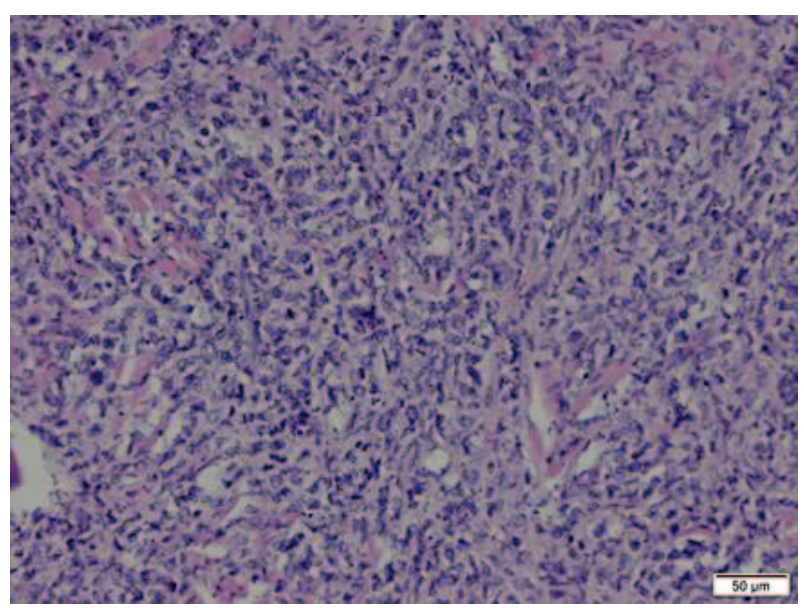

Figure 3. Diffuse infiltration of large centroblasts (hematoxylin and eosin, x 50)

limits. The analysis of B-cell clonality from skin biopsy samples showed monoclonal rearrangement, but bone marrow and blood sample analysis showed polyclonal rearrangement. Bone marrow biopsy was performed and histopathological analysis revealed normal, mature hematopoiesis with no presence of neoplastic cells, both morphologically and immunohistochemically. Peripheral lymph node ultrasound showed no signs of enlarged or pathological lymph nodes. CT scans revealed no signs of central lymphonodopathy or internal organ involvement. PET-CT further excluded extra-cutaneous involvement.

The final diagnosis of primary cutaneous large B-cell lymphoma, other (PCLBCL-O) or primary cutaneous large B-cell lymphoma,

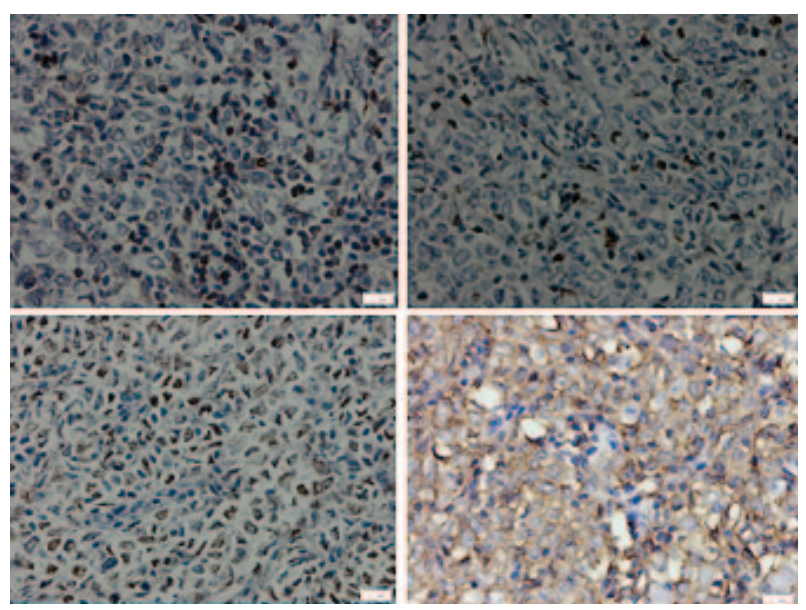

Figure 4. Immunohistochemical staining (a) Bcl2- (b) MUM-1- (c) CD20+ (d) Bcl6+ not otherwise specified (PCLBCL-NOS) was made based on morphology, immunohistochemical and staging evaluations, as well as clonality analysis of the skin, bone marrow and blood samples. The interdisciplinary tumor board decided to perform a surgical excision of the tumor and nodules, and adjuvant radiotherapy after surgery. Recognition of the correct entity led to appropriate therapeutic strategy without relapse on 6-month follow-up (Figure 5).

\section{Discussion}

In the light of overlap between histological and immunophenotypic findings, accurate differentiation of cutaneous B-cell lymphoma $(\mathrm{CBCL})$ from infiltrates of nodal or other extranodal B-cell lymphomas is only possible by means of staging examinations: clinical presentation, laboratory tests, radiologic examinations (MSCT and PET-CT), lymph node biopsy (enlarged nodes) and bone marrow biopsy. Ideally, the diagnosis should be made in centers specializing in cutaneous lymphomas and it is usually made by an interdisciplinary team consisting of dermato-oncologists, hematologists and (dermato-) pathologists (6).

Staging is performed according to the tumor-node-metastasis (TNM) system, which was published in 2008 and evaluates cutaneous spread more adequately than other classifications. The T1 stage corresponds to a solitary lesion, while multiple lesions with involvement of one or two neighboring regions (T2) or more body regions (T3) stand for a higher T stage (7). According to TNM staging, our patient had a T2NOMO stage, since he had multiple lesions limited to one body region without lymph node or systemic involvement.

PCBCL belongs to a distinct group of lymphoproliferative disorders defined by its presentation in the skin without evidence of extracutaneous spread at the time of diagnosis (8). Extranodal involvement occurs in approximately $25 \%$ of non-Hodgkin's lymphomas, with the gastrointestinal tract being the most common site of extranodal involvement, followed by the skin (9). The annual incidence of cutaneous lymphomas is approximately $0.5-1 / 100,000$ (6). PCBCL group accounts for $20 \%-25 \%$ of all primary cutaneous lymphomas (10).

A few studies have used the immunohistochemical expression of CD10, bcl-6, or 


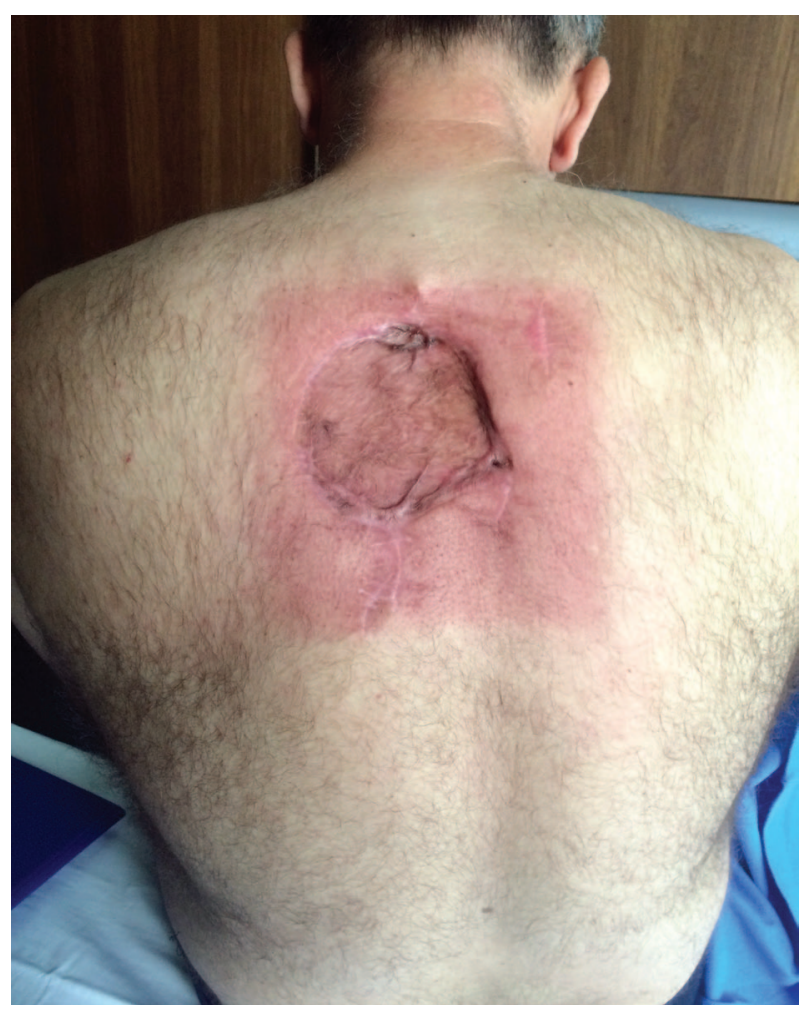

Figure 5. Clinical presentation after treatment

MUM1 to classify cases of DLBCL into GCB (germinal center B-cell) and non-GCB (nongerminal center B-cell) subgroups. Given that bcl-6 and CD10 are markers of germinal center B cells, cases were classified into the GCB group if CD10 alone was positive, or if both bcl- 6 and CD10 were positive. If both bcl- 6 and CD10 were negative, the case was in the non-GCB subgroup. If bcl- 6 was positive and CD10 was negative, the expression of MUM1 determined the group: if MUM1 was negative, the case was in the GCB group; if MUM1 was positive, the case was in the non-GCB group. The 5-year overall survival for the GCB group was $76 \%$ compared with only $34 \%$ for the nonGCB group (11). When it comes to our patient, immunohistochemically, cells were positively stained with Bcl6 and there was no evident expression of CD10 and MUM-1. All of the above puts our patient to the GCB (germinal center B-cell) subgroup of DLBCL which has much better overall survival compared to other subgroups.

The largest study on the subject of PCBCLs was conducted in Italy, and it was published in September 2016. It was a retrospective, multicentric, consensus-based revision of the clinicopathologic characteristics of 161 cases of PCBCL other than MZL. Upon the histologic features, listed in the WHO classification, 96 cases were classified as PCFCCL and 25 as PCDLBCL-LT; however, 40 cases did not fit in the former subgroups in terms of cytology and/or architecture, so they were classified as PCDLBCL, not otherwise specified (PCDLBCL-NOS), previously known as PCDL$\mathrm{BCL}$, other. This study confirmed that another group, CDLBCL-NOS, exists, which can be recognized through a careful combination of histopathologic criteria coupled with adequate clinical information. Separation of PCDLBCLNOS upon histogenetic profile documented a worse prognosis for the non-GC subgroup, whereas cases with a GC profile were more similar to PCFCCL. The first-line treatment was mainly radiotherapy in PCFCCL $(49 \%)$ and in both PCDLBCL-LT (60\%) and PCDLBCL-NOS (55\%). However, follow-up data of PCDLBCLNOS were more similar to PCFCCL in regard to complete response, relapse rate, number of patients alive and disease-free, consistently different from PCDLBCL-LT. The 2-year and 5-year overall survival for both PCFCCL and PCDLBCL-NOS was around 95\%, while for PCDLBCL-LT it was only around $55 \%$. With the limitations of a retrospective data collection, observations from this study suggest the opportunity of a radiotherapy-privileged firstline treatment for PCDLBCL-NOS, particularly in cases with a GC profile (4).

Sokol et al. proposed a PCBCL treatment algorithm (12). The algorithm was based on the present $\mathrm{WHO}$ lymphoma classification, which overcame the previous WHO-EORTC and included at least a part of PCDLBCL-O within the spectrum of PCFCCL. In their opinion, PCMZL and PCFCL (including PCDLBCLO) are low-grade PCBCLs, with an estimated 5-year disease-specific survival rate greater than $95 \%$. Surgical excision or focal radiation therapy is sufficient to control stages T1 and T2 of the disease. Rituximab monotherapy is frequently used for patients with stage T3 disease. PCDLBCL, LT is an intermediate-grade B-cell lymphoma, with a 5-year disease-specific survival rate of approximately $50 \%$. An anthracycline-based chemotherapy regimen with rituximab is usually required as initial therapy to improve the outcome (12).

We decided to perform a surgical excision and perform local radiotherapy, since our 
patient belonged to the germinal center Bcell-like subgroup, with a T2NOMO stage with multiple lesions limited to one body region without lymph node or extra-cutaneous involvement. So far, he is disease-free after the treatment with regular check-ups planned every three months. Recognition of the correct entity led to appropriate therapeutic strategy with favorable outcome.

\section{Conclusion}

In conclusion, primary cutaneous diffuse large B-cell lymphoma, other, represents a rare entity which should be acknowledged as a separate diagnostic category in regard to other primary cutaneous B-cell lymphomas. In patients with solitary or multiple lesions limited to one or two neighboring regions and no extra-cutaneous involvement, an indolent clinical course can be expected. Studies published in the last 5 years recommend surgical excision or local radiotherapy, without chemotherapy, as the best treatment option for these patients. Dermatologists and pathologists should be aware of this entity in order to avoid unnecessary aggressive treatment, especially in cases where the lesions on the skin are localized and there are no signs of systemic involvement.

\section{Abbreviations}

WHO-EORTC - World Health Organization - European Organization for Research and Treatment of Cancer CBCL - cutaneous B-cell lymphoma PCDLBCL-O - primary cutaneous diffuse large $\mathrm{B}$-cell lymphoma, other

PCMZL - primary cutaneous marginal zone B-cell lymphoma PCFCCL - primary cutaneous follicle center cell lymphoma PCDLBCL-LT - primary cutaneous diffuse large B-cell lymphoma, leg type R-CHOP - rituximab + cyclophosphamide, doxorubicin, oncovin and prednisone IHC - immunohistochemical analysis MSCT - Multislice Computed Tomography PET-CT - Positron Emission Tomography

- Computed Tomography TNM - Tumor, Nodes, Metastases FISH - Fluorescence in situ hybridization

\section{References}

1. Swerdlow SH, Campo E, Harris NL, Jaffe ES, Pileri SA, Stein $\mathrm{H}$, et al, editors. WHO classification of tumours of haematopoietic and lymphoid tissues. 4th ed. Lyon: IARC Press; 2008.

2. Willemze R, Jaffe ES, Burg G, Cerroni L, Berti E, Swerdlow $\mathrm{SH}$, et al. WHO/EORTC classification for cutaneous lymphomas. Blood. 2005;105(10):3768-85.

3. LeBoit PE, Burg G, Weedon D, Sarasin A, editors. World Health Organization classification of tumours. Pathology and genetics of skin tumors. 3rd ed. Lyon: IARC Press; 2005

4. Lucioni M, Berti E, Arcaini L, Croci GA, Maffi A, Klersy $C$, et al. Primary cutaneous B-cell lymphoma other than marginal zone: clinicopathologic analysis of 161 cases: comparison with current classification and definition of prognostic markers. Cancer Med. 2016;5(10):2740-55.

5. Selva R, Violetti SA, Delfino C, Grandi V, Cicchelli S, Tomasini $\mathrm{C}$, et al. A literature revision in primary cutaneous B-cell Iymphoma. Indian J Dermatol. 2017;62(2):146-57.

6. Kempf W, Denisjuk N, Kerl K, Cozzio A, Sander C. Primary cutaneous B-cell lymphomas. J Dtsch Dermatol Ges. 2012;10(1):12-22.

7. Kim YH, Willemze R, Pimpinelli N, Whittaker S, Olsen EA, Ranki A, et al. TNM classification system for primary cutaneous lymphomas other than mycosis fungoides and Sezary syndrome: a proposal of the International Society for Cutaneous Lymphomas (ISCL) and the Cutaneous Lymphoma Task Force of the European Organization of Research and Treatment of Cancer (EORTC). Blood. 2007;110(2):479-84.

8. Pandolfino TL, Siegel RS, Kuzel TM, Rosen ST, Guitart J. Primary cutaneous B-cell lymphoma: review and current concepts. J Clin Oncol. 2000;18(10):2152-68.

9. Santucci M, Pimpinelli N. Primary cutaneous B-cell lymphomas. Current concepts. I. Haematologica. 2004;89(11):1360-71.

10. Senff NJ, Noordijk EM, Kim YH, Bagot M, Berti E, Cerroni L, et al. European Organization for Research and Treatment of Cancer and International Society for Cutaneous Lymphoma consensus recommendations for the management of cutaneous B-cell lymphomas. Blood. 2008;112(5):1600-9.

11. Hans CP, Weisenburger DD, Greiner TC, Gascoyne RD, Delabie J, Ott G, et al. Confirmation of the molecular classification of diffuse large B-cell lymphoma by immunohistochemistry using a tissue microarray. Blood. 2004;103(1):275-82.

12. Sokol L, Naghashpour M, Glass LF. Primary cutaneous B-cell lymphomas: recent advances in diagnosis and management. Cancer Control. 2012;19(3):236-44. 


\section{Primarni kutani difuzni B-krupnoćelijski limfom - prikaz slučaja}

\section{Sažetak}

Prema zajedničkoj klasifikaciji Svetske zdravstvene organizacije i Evropske organizacije za istraživanje i lečenje kancera iz 2005. godine, B-ćelijski kutani limfomi su klasifikovani u četiri kategorije: primarni kutani limfom marginalne zone (PCMZL), primarni kutani limfom folikularnog centra (PCFCL), primarni kutani difuzni krupnoćelijski B-limfom lokalizovan na nogama (PCDLBCLLT) i primarni kutani difuzni krupnoćelijski B-limfom, drugi (PCDLBCL-O). Odsustvo ekstrakutane bolesti je neophodan uslov za dijagnozu primarnog kutanog Bćelijskog limfoma, pošto oni imaju potpuno različito kliničko ponašanje i prognozu u odnosu na njihove ekvivalente koji zahvataju limfne noduse. Primarni kutani difuzni krupnoćelijski B-limfom praktično predstavlja difuznu neoplastičnu proliferaciju krupnih B-limfocita (predominantno centroblasta) u koži koja klinički i histološki ne spada ni u grupu PCFCL niti u grupu PCLBCL, leg type. Kliničko ponašanje ovih limfoma se barem parcijalno, ako ne i potpuno, preklapa sa PCFCCL i koji, za razliku od istih limfoma koji zahvataju noduse, imaju odličnu prognozu. Zapravo, trenutna klasifikacija SZO iz 2008. godine prevazišla je prethodnu WHO/EORTC i uvrstila je PCDLBCL-O u spektar PCFCCL. Međutim, uzevši u obzir raritet i heterogenost ovih limfoma, precizne kliničke, histopatološke karakteristike kao i smernice za optimalan terapijski tretman još uvek nisu jasno definisane. Prikaz slučaja. U radu je opisan slučaj četrdesetpetogodišnjeg muškarca sa velikim, asimptomatskim, brzorastućim tumorom i više pojedinačnih nodusa lokalizovanih na koži leđa, paravertebralno levo, čije histopatološke karakteristike odgovaraju primarnom kutanom difuznom krupnoćelijskom B-limfomu (PCDLBCLO). Dosadašnje praćenje našeg pacijenta je pokazalo da, nakon hiruške ekcizije promena i lokalne radioterapije, nema znakova relapsa bolesti. Nisu korišćene dodatne metode lečenja do danas, ali su neophodne redovne tromesečne kontrole. Zaključak. Dermatolozi i patolozi bi trebalo da budu upoznati sa ovim tipom limfoma kao posebnim entitetom, kako bi se izbegle nepotrebne agresivne metode lečenja, naročito u slučajevima gde su lezije na koži lokalizovane i gde nema znakova postojanja sistemske bolesti. Prepoznavanje pravog entiteta dovodi do svrsishodnog terapijskog plana sa povoljnim terapijskim ishodom.

Ključne reči: Difuzni B-krupnoćelijski limfom; Kožne neoplazme; Dijagnoza; Radioterapija; Ishod terapije; Prikazi slučajeva 